\title{
The use of carbonyl group anisotropy effect in determination of the relative configuration of carbapenams
}

\author{
Olga Staszewska-Krajewska, Wojciech Bocian, Magdalena Maciejko, Piotr Szcześniak, \\ Krzysztof Szymczak, Marek Chmielewski, and Bartlomiej Furman* \\ Institute of Organic Chemistry, Polish Academy of Sciences, Kasprzaka 44/52, 01-224; \\ Warsaw, Poland \\ E-mail: bartlomiej.furman@icho.edu.pl
}

\section{Dedicated to Prof. Pierre Vogel on the occasion of his 70th anniversary}

DOI: http://dx.doi.org/10.3998/ark.5550190.p008.450

\begin{abstract}
Assignments of relative configuration of the newly formed stereogenic center at the bridgehead carbon atom of bicyclic carbapenams obtained in Kinugasa reaction can be easily achieved by analyzing chemical shifts of the H-2 proton and geminal protons of the protected alkoxymethyl group at the C-2 carbon atom. The differences of ${ }^{1} \mathrm{H}$ NMR chemical shifts of these protons fall in two ranges of about 3.3-3.7 ppm, and 4.0-4.4 ppm. This observation can be attributed to the influence of the anisotropy of the neighboring carbonyl group and can be easily correlated with configuration at the bridgehead carbon atom.
\end{abstract}

Keywords: Bicyclic $\beta$-lactam, configuration assignment, $\mathrm{C}=\mathrm{O}$ anisotropy effect, ${ }^{1} \mathrm{H}$ NMR, NOE, NICS

\section{Introduction}

It is well known that biological properties of bicyclic $\beta$-lactamic compounds are directly related to the absolute configuration of the stereogenic center at the bridgehead carbon atom. ${ }^{1-4}$ Except for antifungal clavams ${ }^{5-8}$, other biologically active $\beta$-lactams have $(R)$ configuration at that atom (Figure 1). Synthetic efforts directed at the biologically active $\beta$-lactamic products by enantio- or diastereoselective strategies require fast determination of structure and configuration of all intermediate products. It should be also noted that techniques based on the utilization of NOE's are not always unambiguous. Therefore, it would be advantageous to have a fast and unequivocal method to verify the configuration at newly formed stereogenic centers. The absolute configuration of the bridgehead carbon atom, C- 5 at bicyclic $\beta$-lactams, can be established by CD spectroscopy ${ }^{9-16}$ whereas the same assignment by NMR spectroscopy is not always as simple since it may be interlinked to the known configuration of the other stereogenic center. The 
relative configuration of protons in the four-membered ring - the presence of trans or cis substitution pattern, can be determined directly by the analysis of coupling constant between both protons. The range of ${ }^{3} \mathrm{~J}_{\mathrm{H} 5-\mathrm{H} 6}$ coupling constant values for cis- $\beta$-lactams is $5.0-6.5 \mathrm{~Hz}$, whereas for trans- $\beta$-lactams it amounts to $1.5-2.5 \mathrm{~Hz} .^{17}$

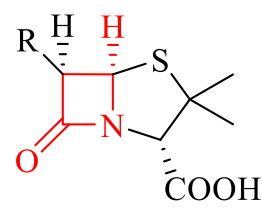

penicillins

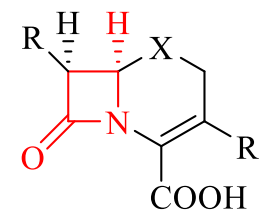

$\mathrm{X}$ : S - cephalosporins $\mathrm{X}$ : O - oxacephems

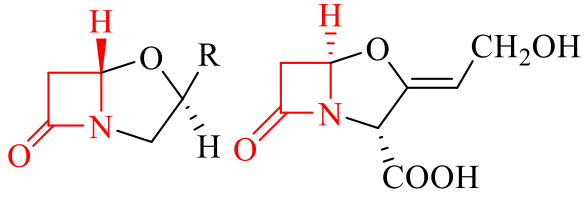

clavams

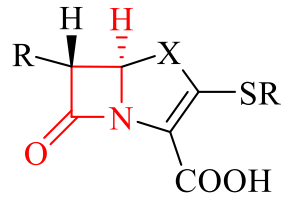

$\mathrm{X}: \mathrm{S}$ - penems $\mathrm{X}: \mathrm{CH}_{2}$ - carbapenems

Figure 1. Representative $\beta$-lactam antibiotics.

\section{Results and Discussion}

In 1980 Bentley and Hunt ${ }^{18}$ investigated ${ }^{1} \mathrm{H}$ NMR spectra of a representative group of $\beta$-lactams and noticed that the difference between chemical shifts $\Delta \delta$ of protons at C-2 carbon atom varied in a range of either 1-1.4 ppm, or 0.4-0.5 ppm. Authors associated this value with configuration at the bridgehead carbon atom. In 1998 we found ${ }^{19}$ that proton H-2 located syn to the lone pair of the nitrogen atom is always shielded in the ${ }^{1} \mathrm{H}$ NMR spectrum with respect to its geminal partner. We have suggested that this relationship may be used for the assignment of the relative configuration. ${ }^{19}$ Recently, using Kinugasa reaction of terminal alkynes with nitrones derived from pentofuranosides, we have synthesized a series of 35 carbapenams. ${ }^{20}$ Analysis of chemical shifts of $\mathrm{H}-2$ and $\mathrm{CH}_{2} \mathrm{OBn}$ protons in NMR spectra of these compounds has shown the same pattern ( $\Delta \delta$ can be correlated with configuration). In all carbapenams the absolute configuration at newly generated stereogenic centers $\mathrm{C}-5$ and $\mathrm{C}-6$, has been substantiated by ${ }^{3} \mathrm{H}_{\mathrm{H} 5 \mathrm{-H} 6}$ coupling constants, NOEs and CD spectroscopy. ${ }^{20}$ Corresponding spectral data of representative group of carbapenams 1-15 are placed in Table 1 (table 1 is continuing in the supplementary material).

Table 1. Selected chemical shifts (in ppm) of carbapenams $\mathbf{1 - 1 5 ^ { 2 0 }}$

\begin{tabular}{lllll}
\hline Entry & Carbapenam & H-2 & $\mathrm{CH}_{2}-\mathrm{OBn}$ & H-2 to H-5 \\
\hline $\mathbf{2}$ & 3 & 3.99 & $3.56,3.61$ & anti \\
\hline
\end{tabular}




\section{Table 1 (continued)}

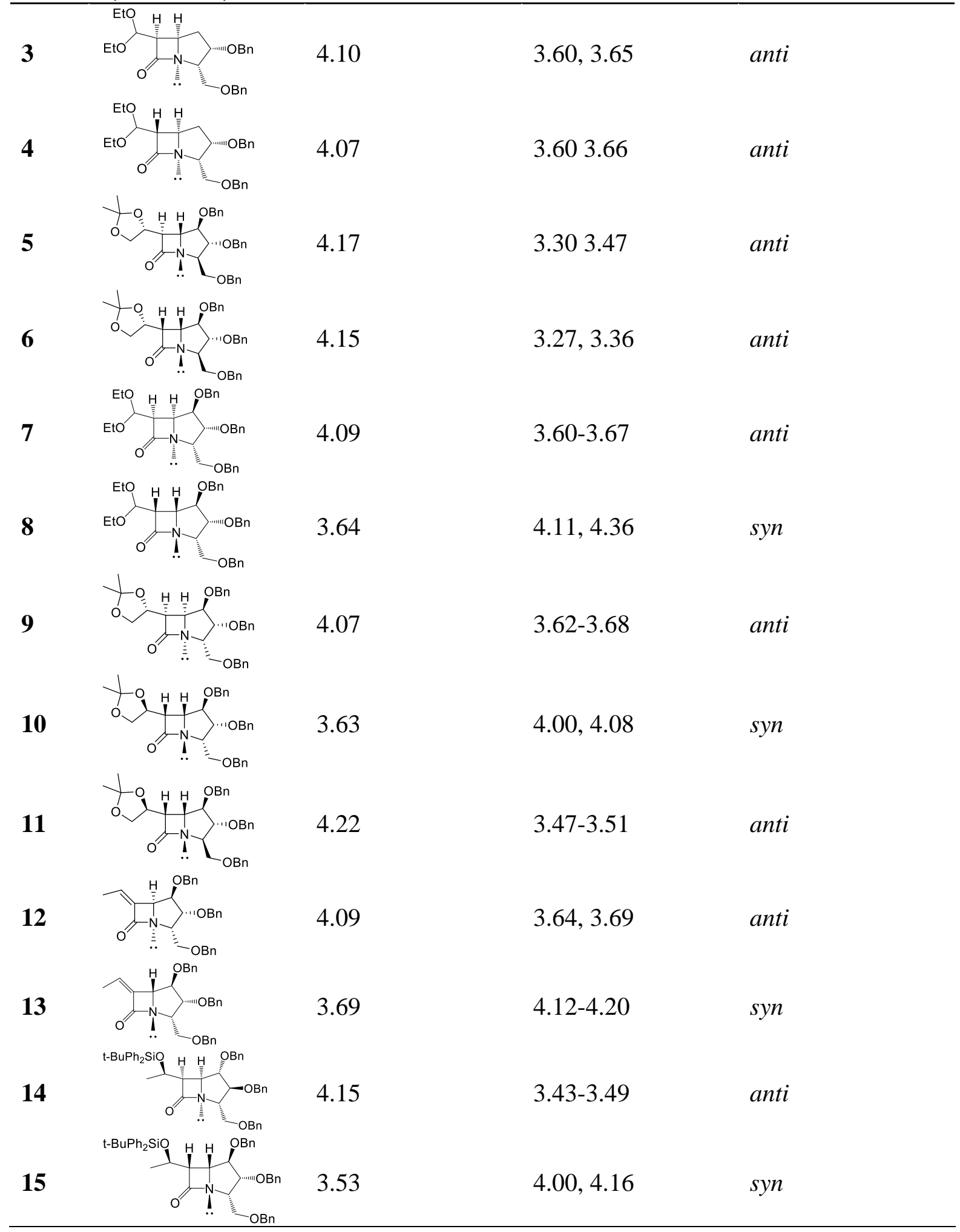

The data for additional 20 carbapenams can found in supplemenetary materials. 
The bicyclic scaffold of carbapenams has an "open-book" geometry ${ }^{21}$ that requires that the $\mathrm{H}-5$ proton, the unshared free electron pair from the nitrogen atom and one of the C-2 substituents are on the convex-side (Figure 2, blue color). The other C-2 substituent is on the concave-side (red color) and is subject to a deshielding contribution to its chemical shift by the magnetically anisotropic carbonyl group. Thus, depending on the spatial arrangement of substituents at the $\mathrm{C}-2$ carbon atom in relation to the free electron pair and the $\beta$-lactam carbonyl group, their chemical shifts fall in two ranges of about either 3.3-3.7 ppm or 4.0-4.4 ppm (Figure 2). Thus, knowing the absolute configuration at C-2 carbon atom, the absolute configuration at the bridgehead carbon atom C-5 can be easily assigned. Generally, protons having higher chemical shifts are in the plane of carbonyl group and therefore deshielded, thus their germinal partners are located cis to the nitrogen lone pair and to the H-5 proton (Figure 2).
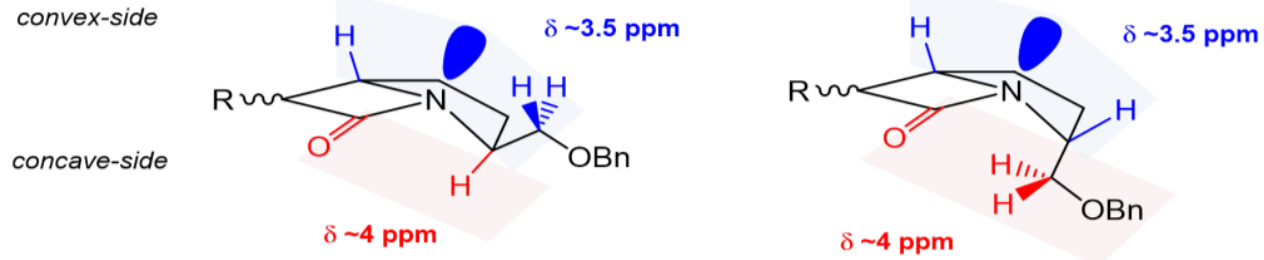

Figure 2. The overview of a geometry of carbapenams.

In 1957 McConnell quantitatively calculated the anisotropy effect of functional groups to explain the respective shielding or deshielding of protons spatially close to the corresponding functional groups. ${ }^{22}$ It should be noted that the McConnell's equation and the resulting "anisotropy cones" predict only the anisotropic effect and are not appropriate for the prediction of the net through-space shielding experienced by a proximal nucleus. This limitation is due to the fact that the overall shielding also includes other factors such as orbital interactions and bond polarization. $^{23}$

It is also evident that for other azabicyclic compounds prepared by us and depicted below, the carbonyl group plays a decisive role in the deshielding effect and the range of changes of chemical shifts caused by the introduction of the carbonyl group (Figure 3). ${ }^{24}$
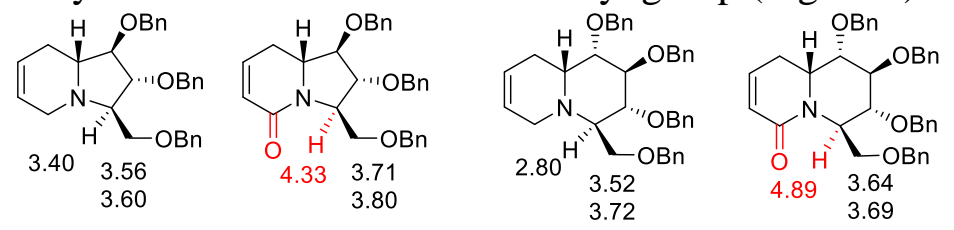

Figure 3. The influence of anisotropy of carbonyl function on the ${ }^{1} \mathrm{H}$ NMR chemical shifts for selected azabicycloalkans. 
In order to test the hypothesis that the carbonyl group anisotropy effect is responsible for the change of observed chemical shifts for $\mathrm{H}-2$ and $\mathrm{CH}_{2}-\mathrm{OBn}$, the DFT calculations were carried out for the set of selected carbapenams $(\mathbf{7}, \mathbf{8}, \mathbf{1 2}, \mathbf{1 3})$ (Table 2).

Table 2. Calculated of spectral and geometrical parameters of compounds 7, 8, 12, and 13

\begin{tabular}{|c|c|c|c|c|}
\hline \multirow{2}{*}{ Carbapenam } & & \multicolumn{3}{|c|}{ NMR Chemical shifts [ppm] } \\
\hline & & H-2 & $\mathrm{CH}_{2}-\mathrm{OBn}$ & H-5 \\
\hline \multirow{5}{*}{ 7 } & $\operatorname{Exp}$ & 4.09 & $3.60-3.67$ & 3.89 \\
\hline & calc A & 4.22 & $3.66 ; 3.84$ & 3.74 \\
\hline & & $(3.64)^{l}$ & $(3.66 ; 3.78)$ & $(3.67)$ \\
\hline & calc B & 4.21 & $3.51 ; 3.77$ & 3.83 \\
\hline & & $(3.54)$ & $(3.51 ; 3.78)$ & $(3.82)$ \\
\hline \multirow{5}{*}{ : } & $\operatorname{Exp}$ & 3.64 & $4.11,4.31-4.42$ & 3.51 \\
\hline & calc A & 3.71 & $4.15 ; 4.76$ & 3.58 \\
\hline & & $(3.75)$ & $(3.97 ; 4.50)$ & $(3.75)$ \\
\hline & calc B & 3.43 & $3.75 ; 4.23$ & 3.30 \\
\hline & & $(3.35)$ & $(3.73 ; 3.80)$ & $(3.48)$ \\
\hline \multirow{9}{*}{ 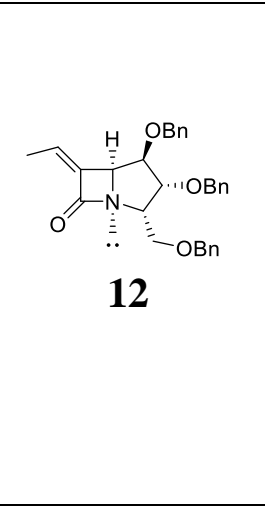 } & $\operatorname{Exp}$ & 4.09 & $3.64,3.69$ & 4.29 \\
\hline & calc A & 4.21 & $3.68 ; 3.87$ & 4.27 \\
\hline & & $(3.89)$ & $(3.53 ; 3.69)$ & $(4.22)$ \\
\hline & calc B & 4.03 & $3.65 ; 3.86$ & 4.13 \\
\hline & & (3.39) & $(3.63 ; 3.65)$ & $(4.09)$ \\
\hline & calc $\mathrm{C}$ & 4.20 & $3.51 ; 3.73$ & 4.39 \\
\hline & & $(3.48)$ & $(3.50 ; 3.73)$ & $(4.48)$ \\
\hline & calc D & 4.20 & $3.52 ; 3.75$ & 4.39 \\
\hline & & $(3.47)$ & $(3.51 ; 3.75)$ & $(4.48)$ \\
\hline \multirow{9}{*}{$\sum_{13}^{\mathrm{OBn}}$} & $\operatorname{Exp}$ & 3.69 & 4.12-4.20 & 4.03 \\
\hline & calc A & 3.56 & $3.81 ; 4.20$ & 3.71 \\
\hline & & $(3.41)$ & $(3.75 ; 3.89)$ & $(3.86)$ \\
\hline & calc B & 3.66 & $3.73 ; 4.26$ & 3.69 \\
\hline & & $(3.49)$ & $(3.68 ; 3.98)$ & $(3.84)$ \\
\hline & calc $\mathrm{C}$ & 3.71 & $4.21 ; 4.66$ & 4.06 \\
\hline & & $(3.62)$ & $(4.00 ; 4.57)$ & $(4.05)$ \\
\hline & calc D & 3.83 & $4.2513 ; 4.6977$ & 4.01 \\
\hline & & $(3.63)$ & $(4.07 ; 4.44)$ & $(4.15)$ \\
\hline
\end{tabular}

1 The NMR chemical shifts for structures with $\mathrm{C}=\mathrm{CH}_{2}$ bond instead of $\mathrm{C}=\mathrm{O}$ are shown in brackets. 
Table 2. Calculated of spectral and geometrical parameters of compounds 7, 8, 12, and 13 (continued)

\begin{tabular}{|c|c|c|c|c|c|}
\hline & $\begin{array}{c}\text { Relative } \\
\text { Energies } \\
{[\mathrm{kcal} / \mathrm{mol}]}\end{array}$ & $\begin{array}{c}\text { Distance } \\
\mathrm{C}=\mathbf{O . . . H 2} \\
{[\AA]}\end{array}$ & $\begin{array}{c}\text { Virtual } \\
\text { dihedral angle } \\
\mathrm{O}=\mathrm{C}-\mathrm{C} 2-\mathrm{H} 2\end{array}$ & $\begin{array}{c}\text { Distance }^{2} \\
\begin{array}{c}\mathrm{C}=\mathbf{O} \ldots \mathrm{H}_{2} \mathrm{C}-\mathrm{OBn} \\
{[\AA]}\end{array}\end{array}$ & $\begin{array}{c}\text { Virtual } \\
\text { dihedral } \\
\text { angle }^{2} \\
\mathrm{O}=\mathrm{C}-\mathrm{C} 2- \\
\mathrm{H}_{2} \mathrm{C}-\mathrm{OBn}\end{array}$ \\
\hline $7 \mathrm{~A}$ & 0.0 & 2.95 & -35.4 & 3.70 & 34.4 \\
\hline $7 B$ & 1.201 & 3.00 & -39.0 & 4.50 & 129.3 \\
\hline $8 \mathrm{~A}$ & 0.0 & 4.14 & -127.9 & 2.58 & 34.2 \\
\hline $8 B$ & 0.943 & 3.86 & -78.2 & 2.76 & -31.3 \\
\hline $12 \mathrm{~A}$ & 0.0 & 2.91 & -34.7 & 3.73 & 35.7 \\
\hline 12B & 0.369 & 2.95 & -38.9 & 3.68 & 32.00 \\
\hline $12 \mathrm{C}$ & 1.449 & 2.94 & -37.0 & 4.55 & 130.8 \\
\hline 12D & 1.452 & 2.94 & -37.1 & 4.54 & 130.4 \\
\hline 13A & 0.0 & 3.85 & -72.4 & 2.72 & -26.6 \\
\hline 13B & 0.151 & 3.84 & -70.2 & 2.76 & -24.9 \\
\hline $13 \mathrm{C}$ & 0.389 & 4.15 & -124.7 & 2.61 & 37.9 \\
\hline 13D & 0.483 & 4.15 & -124.4 & 2.60 & 37.6 \\
\hline
\end{tabular}

${ }^{2}$ The distances and angles are relative to the closest proton from $\mathrm{CH}_{2}-\mathrm{OBn}$ group.

The investigated carbapenams have many flexible substituents, so multiple conformations were generated and tested, however only the lowest energy conformers are described (Table 2, calc AD). The calculations confirmed that the carbapenams have the "open book" geometry and at least one of the substituents is approximately in plane with the carbonyl group. Furthermore, the distance between the carbonyl oxygen and $\mathrm{H}-2$ or $\mathrm{CH}_{2}-\mathrm{OBn}$ substituents is always shorter than 3.0 A. This suggests that the anisotropy effect of carbonyl group can be responsible for the observed deshielding effect on the closest substituents. The calculated NMR chemical shifts confirm this experimental observation for all examined conformations. It is very interesting that this deshielding effect is not observed for the analogous compounds with the carbonyl group replaced by ethylene $\mathrm{C}=\mathrm{CH}_{2}$. (Table 2, the proper values are in parentheses). It is known that the ethenyl has lower anisotropy effect than carbonyl group, which can explain that observation. ${ }^{25}$ Following Schleyer's ${ }^{26}$ and Kleinpeter's ${ }^{25}$ work, we have performed nucleus independent chemical shift (NICS) calculations for our compounds. For best visualization the results are presented as the differential iso-chemical shielding surfaces (ICSS ${ }^{27}$ (Figure 4), where the NICS matrices for compounds with ethylene substituents are subtracted from the NICS for carbonylsubstituted compounds (see Figure 4).

The results clearly show that the anisotropy effect of carbonyl group extends as far as the closest substituents $\mathbf{H}-2$ for compounds 7, 12 and the closer proton from $\mathrm{CH}_{2}$-OBn for 
compounds $\mathbf{8}$ and 13. It is also worth to note that we observe only the differential effect and the full anisotropy of carbonyl group should be even greater. The influence of the lone electron pair of nitrogen atoms has probably a negligible effect on the observed deshielding effects.

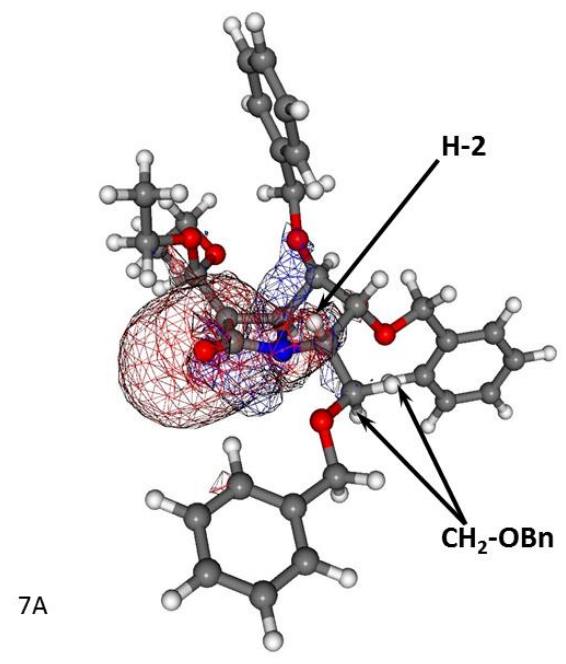

$8 B$

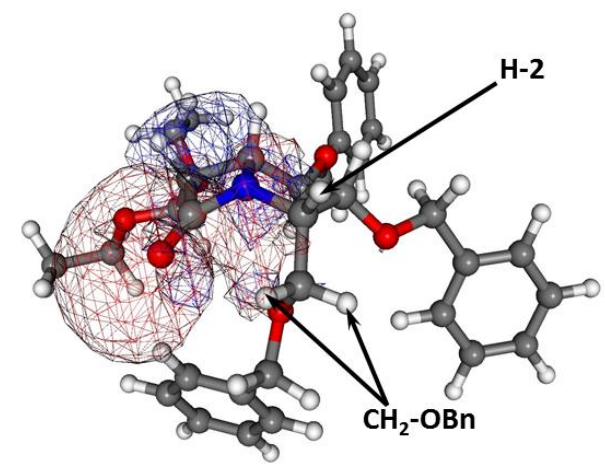

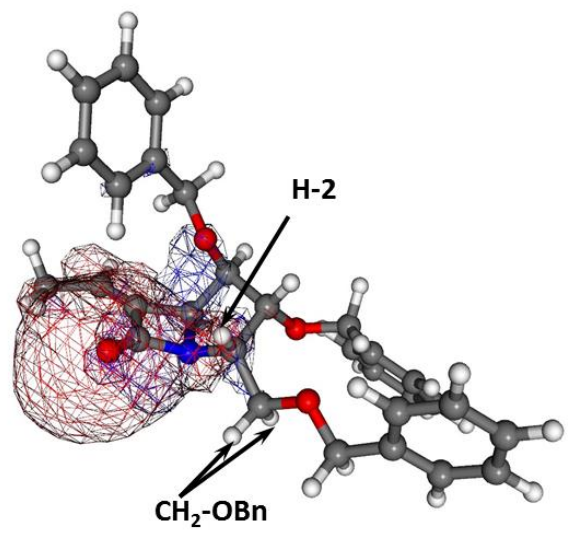

$12 \mathrm{~A}$

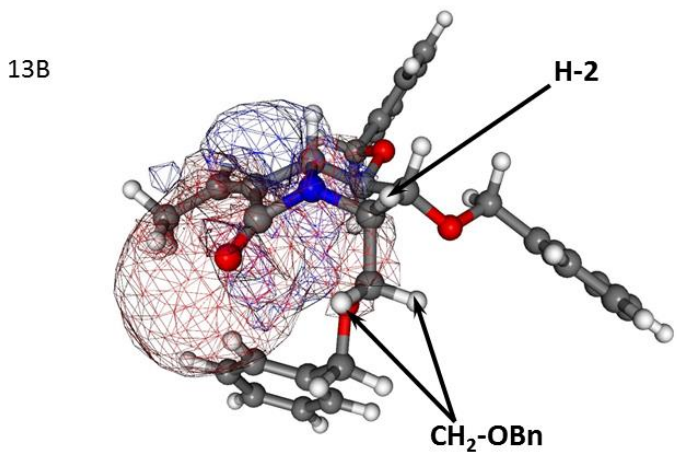

Figure 4. The iso-chemical shielding surfaces (ICSS); red area represents deshielding and blue area represents shielding regions with cutoff $\pm 0.3 \mathrm{ppm}$ (the NICS matrixes for compounds with ethylene substituents are subtracted from the NICS for carbonyl substituted compounds).

\section{Conclusions}

For the shown series of carbapenams, with known absolute configuration at C-2 carbon atom, we are able to determine the configuration of the newly established centers at $\mathrm{C} 5$ and $\mathrm{C} 6$ on the basis of chemical shifts and ${ }^{3} \mathrm{~J}_{\mathrm{H} 5-\mathrm{H} 6}$ alone, without NOE experiments. The observed differences of ${ }^{1} \mathrm{H}$ NMR chemical shifts of $\mathrm{H}-2$ and geminal protons of the protected hydroxymethyl group at $\mathrm{C}$ 2 carbon atom, can be assigned to the influence of the anisotropy of the neighboring carbonyl 
group. The preliminary study showed that the proposed simple relationship could also be used for other azabicyclic compounds.

\section{Computational Methods}

The originally generated structures for compounds 7, 8, 12 and 13 were subjected to conformational grid search using molecular mechanics with MMFFs force field and Monte Carlo algorithm, as implemented in the Spartan software package. ${ }^{28}$ All conformers thus obtained were examined and some additional variations were manually generated. This procedure generated a set of structures for each compound and all of them were further subjected to the DFT quantum chemical geometry optimizations at the B3LYP/6-31G(d) level of theory using the Gaussian 03 program package. ${ }^{29}$ On the basis of calculated electronic energy values a representative structures for each compound were selected and subjected to further analysis. Additionally, using previously selected compounds, the reference structures were built by replacing the carbonyl oxygen with $=\mathrm{CH}_{2}$ groups. The reference structures were energy minimized applying the same DFT algorithm but all atoms, except for the three atoms from added $=\mathrm{CH}_{2}$ group, were restrained in their initial positions. Next, for all the selected and reference structures the magnetic anisotropy effect of unsaturated chemical bonds and the ring current effect have been calculated as the nuclear independent chemical shieldings (NICSs) in a three dimensional grid of lattice points around the molecules. ${ }^{25,30}$ The molecules were placed in the center of a grid of lattice points ranging from -10.0 to $+10.0 \AA$ in all three dimensions with a step width of $0.5 \AA$, resulting in a cube of 68921 lattice points. Due to Gaussian 03 limitations the calculations had to be split into 32 separate runs with the grid points placed no closer than $2 / 2 / 1 \AA$. The chemical shielding calculations were conducted with the GIAO method using DFT B3LYP method and a pcS-1 basis set specialized for chemical shielding calculations. ${ }^{31}$ Finally, the differential NICSs dataset was constructed by subtracting the chemical shieldings matrices for reference structures from the chemical shielding matrices for the given structure and storing results in Gaussian cube format. The iso-chemical-shielding surfaces (ICSS) were visualized using Molekel software. ${ }^{32}$ Red area represents deshielding and blue area indicates shielding regions with cutoff $\pm 0.3 \mathrm{ppm}$.

\section{Acknowledgements}

This research also was financed by the European Union within the European Regional Development Fund, Project POIG.01.01.02.-14-102/09. 


\section{References}

1. Morin, R. B.; Gorman, M., Eds. Chemistry and Biology of $\beta$-Lactam Antibiotics Academic: New York, 1982.

2. Page, M. I., Ed. The Chemistry of $\beta$-Lactams. Blackie Academic \& Professional: New York, 1992.

http://dx.doi.org/10.1007/978-94-011-2928-2

3. Georg, G. I., Ed. The Organic Chemistry of $\beta$-Lactams. Wiley VCH: New York, 1993.

4. Bruggink, A., Ed. Synthesis of $\beta$-Lactam Antibiotics. Kluwer: Dordrecht, 2001. http://dx.doi.org/10.1007/978-94-010-0850-1

5. Brown, D. B.; Evans, J. R.; Fletton, R. A. J. Chem. Soc., Chem. Commun. 1979, $282-283$.

6. Pruess, D. L.; Kellett, M. J. Antibiot. 1983, 36, 208-212. http://dx.doi.org/10.7164/antibiotics.36.208

7. King, H.D.; Langhärig, J.; Sanglier, J. J. J. Antibiot. 1986, 39, 510-515. http://dx.doi.org/10.7164/antibiotics.39.510

8. Cierpucha, M.; Panfil, I.; Danh, T. T.; Chmielewski, M.; Kurzatkowski, W.; Rajnisz, A.; Solecka, J. J. Antibiot. 2007, 60, 622-632.

http://dx.doi.org/10.1038/ja.2007.80

PMid:17965478

9. Łysek, R.; Furman, B.; Kałuża, Z.; Frelek, J.; Suwińska, K.; Urbańczyk-Lipkowska, Z.; Chmielewski, M. Tetrahedron: Asymmetry 2000, 11, 3131-3150. http://dx.doi.org/10.1016/S0957-4166(00)00260-3

10. Łysek, R.; Borsuk, K.; Chmielewski, M.; Kałuża, Z.; Urbańczyk-Lipkowska, Z.; Klimek, A.; Frelek, J. J. Org. Chem., 2002, 67, 1472-1479.

http://dx.doi.org/10.1021/jo010657i

11. Cierpucha, M.; Solecka, J.; Frelek, J.; Szczukiewicz, P.; Chmielewski, M. Bioorg. Med. Chem,. 2004, 12, 405-416.

http://dx.doi.org/10.1016/j.bmc.2003.10.043

12. Frelek, J.; Kowalska, P.; Masnyk, M.; Kazimierski, A.; Korda, A.; Woźnica, M.; Chmielewski, M.; Furche, F. Chem. Eur. J. 2007, 13, 6732-6744. http://dx.doi.org/10.1002/chem.200700127

PMid:17508378

13. Kozioł, A.; Furman, B.; Frelek, J.; Woźnica, M.; Altieri, E.; Chmielewski, M. J. Org. Chem. 2009, 74, 5687-5690.

14. Polavarapu, P. L.; Frelek, J.; Woźnica, M. Tetrahedron: Asymmetry 2011, 22, 1720-1724. http://dx.doi.org/10.1016/j.tetasy.2011.09.008 
15. Woźnica, M.; Butkiewicz, A.; Grzywacz, A.; Kowalska, P.; Masnyk, M.; Michalak, K.; Luboradzki, R.; Furche, F.; Kruse, H.; Grimme, S.; Frelek, J. J. Org. Chem. 2011, 76, 33063319.

http://dx.doi.org/10.1021/jo200171w

PMid:21438506

16. Kwit, M.; Skowronek, P.; Gawronski, J.; Frelek, J.; Woznica, M.; Butkiewicz, A. Some Inherently Chiral Chromophores-Empirical Rules and Quantum Chemical Calculations. In Comprehensive Chiroptical Spectroscopy, John Wiley \& Sons, Inc.: 2012; pp 37-72. http://dx.doi.org/10.1002/9781118120392.ch2

17. Stecko, S.; Mames, A.; Furman, B.; Chmielewski, M. J. Org. Chem. 2009, 74, 3094-3100. http://dx.doi.org/10.1021/jo900121x

PMid:19323546

18. Bentley, P. H.; Hunt, E. J. Chem. Soc., Perkin Trans. 1, 1980, 2222-2227.

19. Furman, B.; Krajewski, P.; Urbańczyk-Lipkowska, Z.; Frelek, J.; Kałuża, Z.; Kozerski, L.; Chmielewski, M. J. Chem. Soc., Perkin Trans. 2, 1998, 1737-1741. http://dx.doi.org/10.1039/a803160f

20. Maciejko, M.; Stecko, S.; Staszewska-Krajewska, O.; Jurczak, M.; Furman, B.; Chmielewski, M. Synthesis 2012, 2825-2839.

21. Nangia, A.; Biradha, K.; Desiraju, G.R. J. Chem. Soc., Perkin Trans. 2, 1996, 943-953. http://dx.doi.org/10.1039/p29960000943

22. McConnell, H. M. J. Chem. Phys. 1957, 27, 226-229.

23. Baranac-Stojanovic, M.; Koch, A.; Kleinpeter, E. Chem. Eur. J. 2012, 18, 370-376. http://dx.doi.org/10.1002/chem.201101882

PMid:22135110

24. Szcześniak, P. unpublished results

25. Klod, S.; Kleinpeter, E. J. Chem. Soc., Perkin Trans. 2, 2001, 1893-1898.

26. Chen, Z.; Wannere, C.S.; Corminboeuf, C.; Puchta, R.; von Rague Schleyer, P. Chem. Rev. 2005, 105, 3842-3888.

http://dx.doi.org/10.1021/cr030088+

PMid:16218569

27. Maier, L.; Solomek, T.; Pipiska, M.; Kriz, Z.; Necas, M.; Marek, R. Tetrahedron 2010, 66, 9277-9285.

http://dx.doi.org/10.1016/j.tet.2010.09.030

28. Spartan'08, Wavefunction, Inc., Irvine, CA. 
29. Frisch, M. J.; Trucks, G. W.; Schlegel, H. B.; Scuseria, G. E.; Robb, M. A.; Cheeseman, J. R.; Montgomery, J. A.; Vreven, Jr., T.; Kudin, K. N.; Burant, J. C.; Millam, J. M.; Iyengar, S. S.; Tomasi, J.; Barone, V.; Mennucci, B.; Cossi, M.; Scalmani, G.; Rega, N.; Petersson, G. A.; Nakatsuji, H.; Hada, M.; Ehara, M.; Toyota, K.; Fukuda, R.; Hasegawa, J.; Ishida, M.; Nakajima, T.; Honda, Y.; Kitao, O.; Nakai, H.; Klene, M.; Li, X.; Knox, J. E.; Hratchian, H. P.; Cross, J. B.; Bakken, V.; Adamo, C.; Jaramillo, J.; Gomperts, R.; Stratmann, R. E.; Yazyev, O.; Austin, A. J. ; Cammi, R.; Pomelli, C.; Ochterski, J. W.; Ayala, P. Y.; Morokuma, K.; Voth, G. A.; Salvador, P.; Dannenberg, J. J.; Zakrzewski, V. G.; Dapprich, S.; Daniels, A. D.; Strain, M. C.; Farkas, O.; Malick, D. K.; Rabuck, A. D.; Raghavachari, K.; Foresman, J. B.; Ortiz, J. V.; Cui, Q.; Baboul, A. G.; Clifford, S.; Cioslowski, J.; Stefanov, B. B.; Liu, G.; Liashenko, A.; Piskorz, P.; Komaromi, I.; Martin, R. L.; Fox, D. J.; Keith, T.; Al-Laham, M. A.; Peng, C. Y.; Nanayakkara, A.; Challacombe, M.; Gill, P. M. W.; Johnson, B.; Chen, W.; Wong, M. W.; Gonzalez, C. and Pople J. A. Gaussian 03, Revision D.02, Gaussian, Inc., Wallingford CT, 2004.

30. Schleyer, P.R.; Maerker, C.; Dansfeld, A.; Jiao, H. and Hommes, N.J.R.E. J. Am. Chem. Soc. 1996, $118,6317$.

http://dx.doi.org/10.1021/ja960582d

31. Jensen, F. J. Chem. Theory Comput. 2008, 4, 719. http://dx.doi.org/10.1021/ct800013z

32. Varetto, Ugo MOLEKEL 5.4.0.8; Swiss National Supercomputing Centre: Lugano (Switzerland). 